\title{
Integrated Risk Study for Chinese Commercial Banks with Fuzzy Comprehensive Appraisal Method
}

Hongmei Li

Haigang Zhou

Cleveland State University, h.zhou16@csuohio.edu

Follow this and additional works at: https://engagedscholarship.csuohio.edu/bus_facpub

Part of the Finance and Financial Management Commons, and the International Business Commons How does access to this work benefit you? Let us know!

\section{Publisher's Statement}

(C) Inderscience

\section{Original Published Citation}

Li, H., Zhou, H. (2013). Integrated Risk Study for Chinese Commercial Banks with Fuzzy Comprehensive Appraisal Method. International Journal of Financial Services Management, 6(4), pp. 334-351.

This Article is brought to you for free and open access by the Monte Ahuja College of Business at EngagedScholarship@CSU. It has been accepted for inclusion in Business Faculty Publications by an authorized administrator of EngagedScholarship@CSU. For more information, please contact library.es@csuohio.edu. 


\title{
Integrated risk study for Chinese commercial banks with fuzzy comprehensive appraisal method
}

\author{
Hongmei Li* \\ School of Mathematics, \\ Liaoning University, \\ Shenyang 110036, China \\ Email: sunnymei2003@gmail.com \\ *Corresponding author

\section{Haigang Zhou} \\ Department of Finance, \\ Cleveland State University, \\ $\mathrm{OH} 44115-2214$, USA \\ Email: h.Zhou16@csuohio.edu
}

\begin{abstract}
The Basel Capital Accord II proposes that commercial banks should supervise not only credit risk but also market risk, liquidity risk and operational risk. Using the fuzzy comprehensive appraisal method based on the Basel Capital Accord II, this paper measures the integrated risk of Chinese commercial banks. Our results indicate that the average values of the four types of risks are higher than the integrated risk of the four risks, indicating an overestimated whole risk. Our results illustrate the importance of considering the correlation between the different risk sources in order to efficiently allocate financial resources.
\end{abstract}

Keywords: integrated risk of commercial bank; fuzzy comprehensive appraisal; R-cluster analysis; principal component analysis.

Reference to this paper should be made as follows: $\mathrm{Li}, \mathrm{H}$. and Zhou, H. (2013) 'Integrated risk study for Chinese conmercial banks with fuzzy comprehensive appraisal method', Int. J. Financial Services Management, Vol. 6, No. 4, pp.334-351.

Biographical notes: Hongmei $\mathrm{Li}, \mathrm{PhD}$, is a Lecturer at School of Mathematic in Liaoning University. She received her $\mathrm{PhD}$ in Finance from Liaoning University in July 2010. She has been teaching advanced mathematics to undergraduate at Liaoning University since August 2005. Her research interests are financial engineering (risk management of commercial banks), time series analysis, and mathematical finance. Her research has been published in many financial and mathematical journals.

Haigang Zhou received his $\mathrm{PhD}$ in Finance from the University of NebraskaLincoln in August 2006, and was awarded the Certified Financial Analyst (CFA) charterholdership in April 2006. He has been teaching undergraduate, MBA and doctoral courses at CSU since August 2006. His research interests 
are in investments, corporate govemance, executive compensation, international financial management, and behavioural finance. His research has been published or forthcoming in many premier finance journals and presented at top finance conferences internationally.

\section{Introduction}

With the increase in complexity of financial transactions, commercial banks face an integrated risk of credit, market, operation and so on. There are strong correlations among these risks. The conventional method of measuring individual risks ignores the correlations, and thus does not fully reflect the true level of risk exposure of the bank. In addition, Basel II (Basel Committee on Banking Supervision, 2006) proposes measuring the risks in an integrated manner.

Although the commercial banks in China have improved the measurement of credit, market, operational and liquidity risks, these risks are usually measured independently and in an isolated manner. This paper measures the integrated risk of Chinese commercial banks. According to the Banker magazine, Industrial and Commercial Bank of China (ICBC) and China Construction Bank (CCB) represent large commercial banks in China. China Merchant Bank (CMB) and Shanghai Pudong Development Bank (SPDB) are regarded as the representative of Chinese publicly traded commercial banks. In this paper, we will measure the integrated risk of the four commercial banks using the fuzzy comprehensive appraisal method. From this paper, we can draw a conclusion that the mean value of the four risks will be higher than the integrated risk of the four risks considering the correlations between risks. This means the whole risk will be overestimated. This is not conducive to the allocation efficiency of financial resources.

The remainder of the paper is organised as follows. The research model is formulated in Section 3, and the empirical analysis is provided in Section 4. In Section 5, we offer the summary and conclusions.

\section{Literature review}

In the risk research area of commercial banks, many scholars have conducted much research regarding all kinds of risks. However, in recent years, both integrated risks and comprehensive appraisals are beginning to be studied. Frankel and Rose (1996) developed a probit model of currency crashes in a large sample of developing countries. Their use of annual data permitted them to make a comprehensive appraisal with these variables (such as the composition of external debt) that were available only at that frequency. Rosenberg and Schuermann (2006) constructed the integrated risk distribution for a typical, large, internationally active bank using the method of copulas. He and Zhang (2001) established a risk pre-warning system for commercial banks with an integrated evaluation method. Zhang and Huang (2003) analysed factors for financial risk 
evaluation, obtained the indexes weights with hierarchical analysis and valued the risk of integrated financial systems with a comprehensive appraisal method. Chen (2003) introduced several statistical methods of risk rating. Chi et al. (2009) set up an early warning model of commercial banks" risk based on a comprehensive appraisal and principal component analysis.

Many of the above approaches did not study the integrated risks of credit, market, liquidity and operation. This paper will measure the credit, market, operational and liquidity risks as a whole faced by the Chinese commercial banks using fuzzy comprehensive appraisal and an objective analysis method. Different from others, our study includes operational risk in the integrated risk. Without operational risk data in the annual report of Chinese commercial banks, this paper tries to measure the operational risk of the commercial banks indirectly.

\section{Research model}

\subsection{Primaries of the integrated risk indexes}

According to the requirements of 'risk evaluation system of commercial banks (interim)' and 'commercial bank regulatory risk core index (interim)' (China Banking Regulatory Commission, 2004, 2005) in China, we selected 13 indexes from the four aspects of the credit, market, operational and liquidity risks in view of the indexes selection principles and expert opinions. $X_{1}, X_{2}, X_{3}$ and $X_{4}$ represented the four kinds of risks, respectively. $\left(X_{11}, X_{12}, X_{13}, X_{14}, X_{15}, X_{16}\right),\left(X_{21}, X_{22}\right),\left(X_{31}\right)$ and $\left(X_{41}, X_{42}, X_{43}, X_{44}\right)$ represented the second-layer indexes (see Table 1). Table 1 presents the different risks' indexes and the limit for each index.

Table 1 Primary indexes of the integrated risk

\begin{tabular}{clc}
\hline \multicolumn{1}{c}{ Sort } & \multicolumn{1}{c}{ Index } & Limit \\
\hline & Non-performing loan ratio $\left(X_{11}\right)$ & $5 \%$ \\
& Estimated loan loss ratio $\left(X_{12}\right)$ & $3 \%$ \\
Credit risk $\left(X_{1}\right)$ & Mortgage loans ratio $\left(X_{13}\right)$ & $25 \%$ \\
& NPL provisioning coverage ratio $\left(X_{14}\right)$ & $75 \%$ \\
& Ratio of the largest single loan $\left(X_{15}\right)$ & $10 \%$ \\
& Ratio of 10 largest loans $\left(X_{16}\right)$ & $50 \%$ \\
\hline \multirow{2}{*}{ Market risk $\left(X_{2}\right)$} & Risk-sensitive ratio of interest rate $\left(X_{21}\right)$ & 1 best \\
& Accumulated foreign exchange exposure positions ratio $\left(X_{22}\right)$ & $20 \%$ \\
\hline Operational risk $\left(X_{3}\right)$ & The volatility of non-interest expenditure $\left(X_{31}\right)$ & $40 \%$ \\
\hline & Reserve requirement ratio $\left(X_{41}\right)$ & $13.5 \%$ \\
& Liquidity ratio $\left(X_{42}\right)$ & $25 \%$ \\
Liquidity risk $\left(X_{4}\right)$ & Loan-deposit ratio $\left(X_{43}\right)$ & $75 \%$ \\
& Inter-bank borrowings ratio $\left(X_{44}\right)$ & $4 \%$ \\
\hline
\end{tabular}


We used the 2005-2008 volatility of non-interest expenditure calculated by the top-down expenditure approach to represent the index of operational risk. Though this substitution cannot value the precise operational risk, it can make a rough comparison of operational risk between commercial banks.

Then we will determine the integrated risk indexes of these commercial banks.

\subsection{Determination of the integrated risk indexes}

Because of the different dimensions between these indexes, the data will be dealt with dimensionless method.

\subsubsection{Dimensionless method of indexes}

The formulas of dimensionless method are $X^{\prime}=X_{r} / X_{m}$ with the forward indexes and $X^{\prime}=X_{m} / X_{i}$ with the backward indexes. Let $X^{\prime}=$ dimensionless indexes, $X_{i}=$ true value and $X_{m}=$ limit value in Table 1 .

These index data in the 2008 annual report of the four banks are dealt with this dimensionless method and the dimensionless data of the integrated risk indexes are given in Table 2. ICBC, CCB, SPDB and CMB stand for Industrial and Commercial Bank of China, China Construction Bank, Shanghai Pudong Development Bank and China Merchant Bank, respectively.

Table 2 Dimensionless data of integrated risk indexes

\begin{tabular}{lcccc}
\hline \multicolumn{1}{c}{ Index } & ICBC & CCB & SPDB & CMB \\
\hline Non-performing loan ratio $\left(X_{11}\right)$ & 2.18 & 2.26 & 4.13 & 4.50 \\
Estimated loan loss ratio $\left(X_{12}\right)$ & 1.44 & 1.48 & 1.98 & 1.76 \\
Mortgage loans ratio $\left(X_{13}\right)$ & 2.07 & 2.16 & 1.82 & 1.51 \\
NPL provisioning coverage ratio $\left(X_{14}\right)$ & 1.74 & 1.75 & 2.57 & 2.98 \\
Ratio of the largest single loan $\left(X_{15}\right)$ & 3.45 & 2.72 & 3.38 & 1.88 \\
Ratio of 10 largest loans $\left(X_{16}\right)$ & 2.45 & 2.41 & 2.06 & 1.56 \\
Risk-sensitive ratio of interest rate $\left(X_{21}\right)$ & 0.93 & 0.93 & 0.97 & 0.92 \\
Accumulated foreign exchange exposure positions ratio $\left(X_{22}\right)$ & 2.28 & 6.47 & 1.39 & 1.73 \\
The volatility of non-interest expenditure $\left(X_{31}\right)$ & 1.01 & 1.56 & 0.94 & 0.95 \\
Reserve requirement ratio $\left(X_{41}\right)$ & 1.07 & 1.07 & 1.00 & 1.00 \\
Liquidity ratio $\left(X_{42}\right)$ & 1.33 & 2.11 & 2.21 & 1.73 \\
Loan-deposit ratio $\left(X_{43}\right)$ & 1.33 & 1.30 & 1.03 & 1.01 \\
Inter-bank borrowings ratio $\left(X_{44}\right)$ & 6.15 & 50.00 & 3.57 & 1.14 \\
\hline
\end{tabular}

\subsubsection{Cluster analysis of indexes}

After the non-dimension, we will do correlation analysis on these data with the SPSS software to get the correlative matrix of the risk indicators. The correlative matrix is presented in Table 3 . The result indicates that there are strong correlations between some of the risk indicators. 


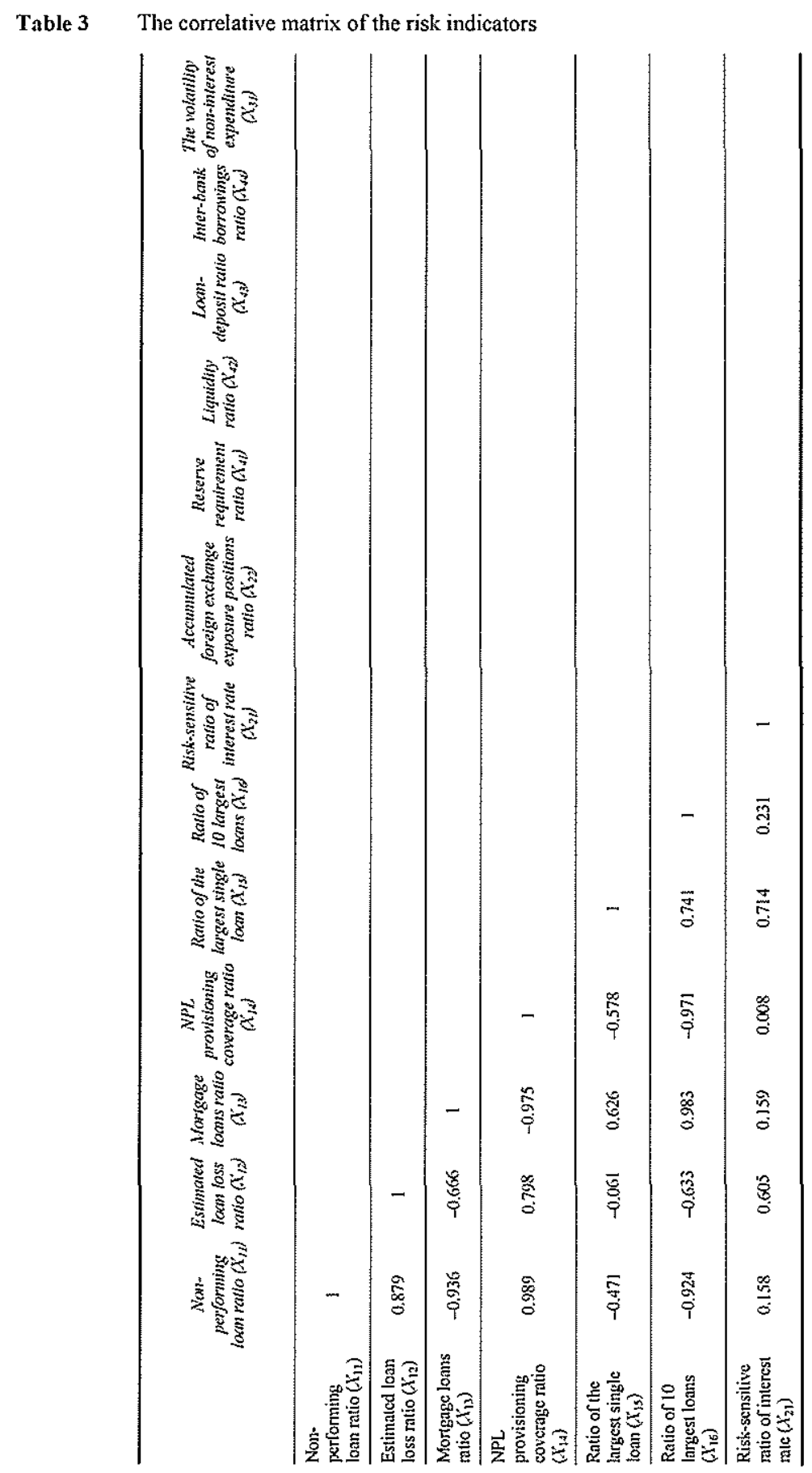




\begin{tabular}{|c|c|c|c|c|c|c|c|c|c|c|c|c|c|}
\hline & $\begin{array}{c}\text { Non- } \\
\text { purforming } \\
\text { locan ratio } X_{i l}\end{array}$ & $\begin{array}{l}\text { Essimated } \\
\text { lean loss } \\
\text { ratio }\left(X_{t 2}\right)\end{array}$ & $\begin{array}{l}\text { M. Morrgage } \\
\text { loans ratio } \\
\left(R_{i j}\right)\end{array}$ & $\begin{array}{c}N P L \\
\text { provisioning } \\
\text { coverage rafio } \\
\left(X_{t, t}\right)\end{array}$ & $\begin{array}{l}\text { Ratio of the } \\
\text { largest single } \\
\text { loan }\left(\lambda_{t i}\right)\end{array}$ & $\begin{array}{l}\text { Ratio of } \\
\text { lo largest } \\
\text { loans }\left(\hat{X}_{t \delta}\right)\end{array}$ & $\begin{array}{l}\text { Risht-sensitive } \\
\text { ratio of } \\
\text { inferestrate } \\
\left.\Omega_{22}\right)^{2}\end{array}$ & $\begin{array}{l}\text { Accumulated } \\
\text { foretign exchange } \\
\text { expossurt positions } \\
\text { ratio }\left(x_{22}\right)\end{array}$ & $\begin{array}{c}\text { Reserve } \\
\text { requirement } \\
\text { ratio }\left(X_{t}\right)\end{array}$ & $\begin{array}{l}\text { Liquididity } \\
\text { ratio }(x, y)\end{array}$ & 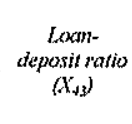 & 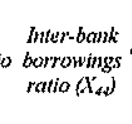 & 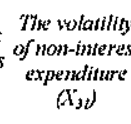 \\
\hline $\begin{array}{l}\text { Accunulaled } \\
\text { forcign } \\
\text { exclange } \\
\text { exposure } \\
\text { positions ratio } \\
\left(X_{22}\right) \\
\end{array}$ & -0.655 & -0.607 & 0.684 & -0.636 & $\rightarrow-100$ & 0.541 & -0.266 & 1 & & & & & \\
\hline $\begin{array}{l}\text { Resecrve } \\
\text { requirctent } \\
\text { ratio }\left(X_{41}\right)\end{array}$ & -0.992 & -0.930 & 0.893 & -0.962 & 0.359 & 0.869 & -0.280 & 0.687 & 1 & & & & \\
\hline $\begin{array}{l}\text { Liquidity ratio } \\
\left(X_{42}\right)\end{array}$ & 0.313 & 0.567 & 0.000 & 0.218 & -0.039 & -0.095 & 0.555 & 0.301 & -0.356 & 1 & & & \\
\hline $\begin{array}{l}\text { Loan-dedposit } \\
\text { ratio }\left(X_{43}\right)\end{array}$ & -0.996 & -0.916 & 0.899 & -0.971 & 0.425 & 0.890 & -0.235 & 0.627 & 0.996 & -0.393 & 1 & & \\
\hline $\begin{array}{l}\text { Inter-bank } \\
\text { borrowings } \\
\text { ratio }\left(X_{t+1}\right)\end{array}$ & $-0,618$ & -0.521 & 0.690 & -0.616 & -0.051 & 0.547 & -0.156 & 0.993 & 0.638 & 0.404 & 0.579 & 1 & \\
\hline $\begin{array}{l}\text { The volatility } \\
\text { of non-interest } \\
\text { expenditure } \\
\left(\lambda_{11}\right)\end{array}$ & -0.630 & -0.559 & 0.682 & -0.619 & -0.083 & 0.537 & -0.212 & 0.998 & 0.657 & 0.359 & 0.597 & 0.998 & 1 \\
\hline
\end{tabular}


Then we will eliminate some indexes which have strong correlations. Here we use Rcluster analysis. Clustering means to divide all the data into different clusters. R-cluster analysis is a classification method based on the correlation coefficients or the distance between different indexes. Here we use squared Euclidean $\left[\Sigma\left(X_{i}-Y_{i}\right)^{2} ;\right.$ see Verma, 2013]. We can get the indexes classification and distance cluster combine. Table 4 and Figure 1 indicate the classification results between these indexes with R-cluster analysis.

Table 4 Indexes classification with R-cluster analysis

\begin{tabular}{|c|c|c|c|c|c|c|c|c|}
\hline Case & $\begin{array}{c}12 \\
\text { chisters }\end{array}$ & $\begin{array}{l}\text { Il } \\
\text { chisters }\end{array}$ & $\begin{array}{c}\text { lo } \\
\text { chustersch }\end{array}$ & $\begin{array}{l}9 \\
\text { chistersc }\end{array}$ & $\begin{array}{c}8 \\
\text { clusters }\end{array}$ & $\begin{array}{c}7 \\
\text { s clusters }\end{array}$ & $\begin{array}{c}6 \\
\text { chusters }\end{array}$ & $\begin{array}{c}5 \\
\text { chusters }\end{array}$ \\
\hline Non-performing loan ratio $\left(X_{11}\right)$ & 1 & l & 1 & 1 & 1 & 1 & 1 & 1 \\
\hline Estimated loan loss ratio $\left(X_{12}\right)$ & 2 & 2 & 2 & 2 & 2 & 2 & 1 & 1 \\
\hline Mortgage loans ratio $\left(X_{13}\right)$ & 3 & 3 & 3 & 3 & 3 & 3 & 2 & 2 \\
\hline $\begin{array}{l}\text { NPL provisioning coverage } \\
\text { ratio }\left(X_{14}\right)\end{array}$ & 4 & 4 & 4 & 1 & 1 & 1 & 1 & 1 \\
\hline $\begin{array}{l}\text { Ratio of the largest single loan } \\
\left(\mathrm{X}_{15}\right)\end{array}$ & 5 & 5 & 5 & 4 & 4 & 4 & 3 & 3 \\
\hline Ratio of 10 largest loans $\left(X_{16}\right)$ & 6 & 6 & 6 & 5 & 3 & 3 & 2 & 2 \\
\hline $\begin{array}{l}\text { Risk-sensitive ratio of interest } \\
\text { rate }\left(X_{21}\right)\end{array}$ & 7 & 7 & 7 & 6 & 5 & 5 & 4 & 3 \\
\hline $\begin{array}{l}\text { Accumulated foreign exchange } \\
\text { exposure positions ratio }\left(X_{22}\right)\end{array}$ & 8 & 8 & 8 & 7 & 6 & 6 & 5 & 4 \\
\hline Reserve requirement ratio $\left(X_{41}\right)$ & 9 & 9 & 9 & 8 & 7 & 3 & 2 & 2 \\
\hline Liquidity ratio $\left(X_{42}\right)$ & 10 & 10 & 10 & 9 & 8 & 7 & 6 & 5 \\
\hline Loan-deposit ratio $\left(X_{43}\right)$ & 11 & 9 & 9 & 8 & 7 & 3 & 2 & 2 \\
\hline $\begin{array}{l}\text { Inter-bank borrowings ratio } \\
\left(X_{44}\right)\end{array}$ & 12 & 11 & 8 & 7 & 6 & 6 & 5 & 4 \\
\hline $\begin{array}{l}\text { The volatility of non-interest } \\
\text { expenditure }\left(X_{31}\right)\end{array}$ & 12 & 11 & 8 & 7 & 6 & 6 & 5 & 4 \\
\hline
\end{tabular}

Figure 1 Rescaled distance cluster combine

\begin{tabular}{ccccccc}
$\begin{array}{c}\text { Case } \\
\text { Label Num }\end{array}$ & 0 & 5 & 10 & 15 & 20 & 25 \\
\hline
\end{tabular}

$\begin{array}{cc}X_{44} & 12 \\ X_{31} & 13 \\ X_{22} & 8 \\ X_{41} & 9 \\ X_{43} & 11 \\ X_{13} & 3 \\ X_{16} & 6 \\ X_{15} & 5 \\ X_{21} & 7 \\ X_{11} & 1 \\ X_{14} & 4 \\ X_{12} & 2 \\ X_{42} & 10\end{array}$

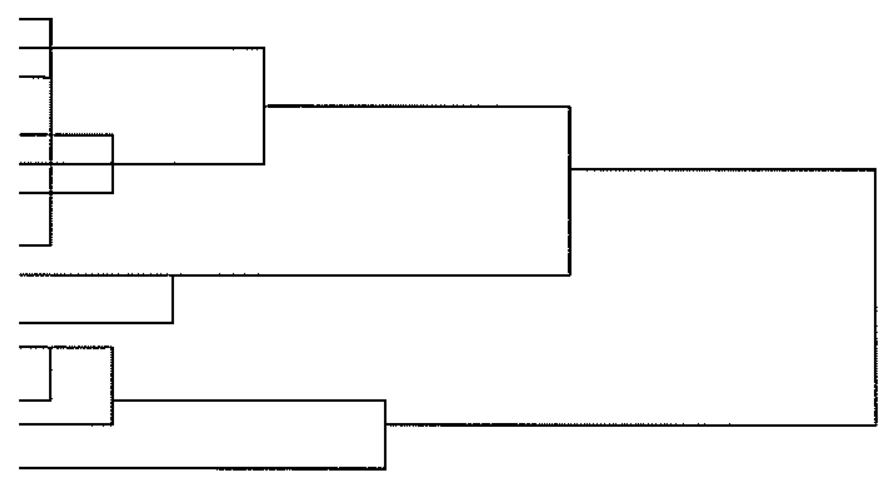


There is the strongest relation between $X_{11}$ and $X_{14} . X_{13}$ and $X_{16}$ belong to the same category. $X_{31}$ and $X_{44}$ are in the same category. There is some relation between $X_{41}$ and $X_{43}$.

Considering the representation and correlation of these indexes, we set up the index system of the integrated risk in Figure 2 according to the result of R-cluster analysis.

Figure 2 Integrated risk index system of commercial banks

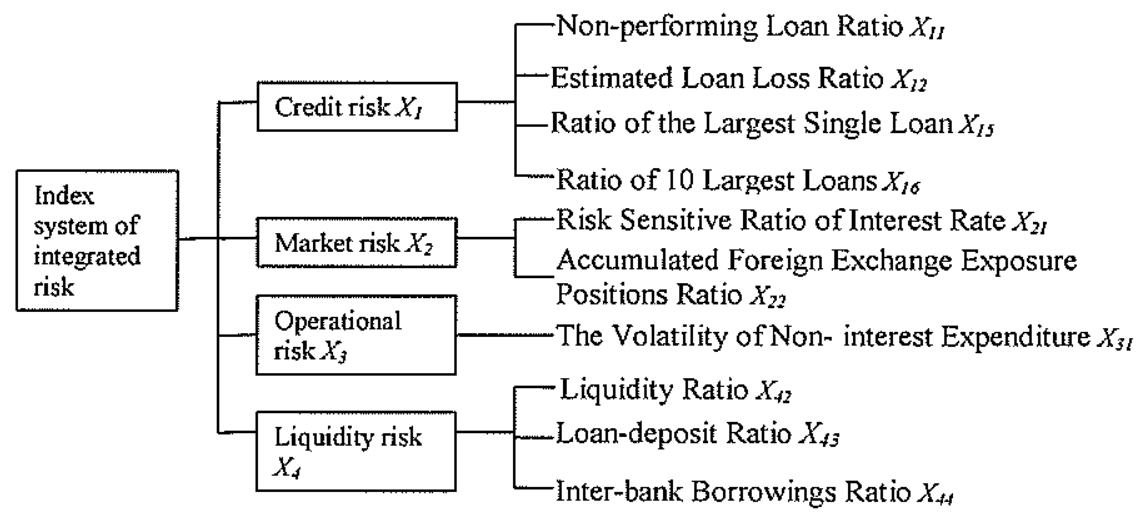

\subsection{Indexes weights of integrated risk}

This paper will get the index weights of the integrated risk with objective principal component analysis. Principal component analysis is a method of reduction of dimension. Multiple variables are reduced to a small number of variables (called principal components) through this method. If we use the random variable $X=\left(X_{1}, X_{2}, \ldots, X_{p}\right)^{\mathrm{T}}$ to describe the research objects, then we can get the linear transformations of $X$ with the principal component analysis:

$$
\left\{\begin{array}{c}
Z_{1}=\mu_{11} X_{1}+\mu_{12} X_{2}+\ldots+\mu_{1 p} X_{p} \\
Z_{2}=\mu_{21} X_{1}+\mu_{22} X_{2}+\ldots+\mu_{2 p} X_{p} \\
\ldots \ldots \ldots \\
Z_{q}=\mu_{q 1} X_{1}+\mu_{q 2} X_{2}+\ldots+\mu_{q p} X_{p}
\end{array}\right.
$$

In the linear transformations of $X, Z_{1}, Z_{2}, \ldots, Z_{q}$ are the principal components. $\mu_{i j}$ $(i=1,2, \ldots, q, j=1,2, \ldots, p)$ is the coefficient of the principal components (see Jolliffe, 2002). With the SPSS software, principal component analysis is used on the dimensionless data of the index system. Then, we can get the coefficient matrix of the principal component score. The result is given in Table 5 . 
Table 5 Coefficient matrix of principal component score

\begin{tabular}{|c|c|c|c|}
\hline \multirow{2}{*}{ Indexes } & \multicolumn{3}{|c|}{ The coefficient of principal component } \\
\hline & I & 2 & 3 \\
\hline Non-performing loan ratio $\left(X_{11}\right)$ & -0.173 & -0.112 & 0.083 \\
\hline Estimated loan loss ratio $\left(X_{12}\right)$ & -0.157 & 0.053 & 0.220 \\
\hline Ratio of the largest single loan $\left(X_{15}\right)$ & 0.047 & 0.423 & 0.041 \\
\hline Ratio of 10 largest loans $\left(X_{16}\right)$ & 0.153 & 0.238 & 0.024 \\
\hline Risk-sensitive ratio of interest rate $\left(X_{21}\right)$ & -0.045 & 0.330 & 0.274 \\
\hline $\begin{array}{l}\text { Accumulated foreign exchange exposure positions } \\
\text { ratio }\left(X_{22}\right)\end{array}$ & 0.156 & -0.161 & 0.161 \\
\hline The volatility of non-interest expenditure $\left(X_{31}\right)$ & 0.153 & -0.153 & 0.187 \\
\hline Liquidity ratio $\left(X_{42}\right)$ & -0.020 & -0.046 & 0.442 \\
\hline Loan-deposit ratio $\left(X_{43}\right)$ & 0.171 & 0.096 & -0.121 \\
\hline Inter-bank borrowings ratio $\left(X_{44}\right)$ & 0.150 & -0.139 & 0.208 \\
\hline
\end{tabular}

Table 5 is the result of the principal component analysis method. From Table 5 , we can get three principal components. Let $Z$ stand for comprehensive principal component. According to the coefficient matrix of the principal component score, we can get the linear combination between the principal components and the early risk warning indexes. The coefficients of the principal components are the contribution rate of each index to the principal components. Based on the contribution rate of each index to the principal components, we can get equations (1)-(4):

$$
\begin{aligned}
Z_{1} & =-0.173 X_{11}-0.157 X_{12}+0.047 X_{15} \\
& +0.153 X_{16}-0.045 X_{21}+0.156 X_{22} \\
& +0.153 X_{31}-0.02 X_{42}+0.171 X_{43}+0.15 X_{44} \\
Z_{2} & =-0.112 X_{11}+0.053 X_{12}+0.423 X_{15} \\
& +0.238 X_{16}+0.33 X_{21}-0.161 X_{22} \\
& -0.153 X_{31}-0.046 X_{42}+0.096 X_{43}-0.139 X_{44} \\
Z_{3} & =0.083 X_{11}+0.22 X_{12}+0.041 X_{15} \\
& +0.024 X_{16}+0.274 X_{21}+0.161 X_{22} \\
& +0.187 X_{31}+0.442 X_{42}-0.121 X_{43}+0.208 X_{44} \\
Z= & 0.549 Z_{1}+0.2274 Z_{2}+0.2236 Z_{3}
\end{aligned}
$$

Substituting equations (1)-(3) into equation (4), we have equation (5):

$$
\begin{aligned}
Z= & -0.102 X_{11}-0.025 X_{12}+0.131 X_{15} \\
& +0.143 X_{16}+0.112 X_{21}+0.085 X_{22} \\
& +0.091 X_{31}+0.077 X_{42}-0.089 X_{43}+0.097 X_{44}
\end{aligned}
$$

Equation (5) is the equation of the linear relationship between comprehensive principal component and the early risk warning indexes. That is the index contribution degree to 
the comprehensive principal component. The coefficient in equation (5) is the weight of each index. For comparing conveniently, the coefficients of equation (5) are normalised. The normalised procedure is as follows:

1 Add up all the absolute values of the coefficients. $s=\sum_{i=1}^{4} \sum_{j}\left|a_{i j}\right|$, where $a_{i j}$ is the coefficient of the indexes in equation (5).

2 Calculate separately the absolute value sum of each index's coefficient in the first layer. $s_{i}, i=1,2,3,4$.

- Weight of first-layer index: $w_{i}=s_{i} / s, i=1,2,3,4$.

- Weight of second-layer index: $w_{i f}=\left|a_{i j}\right| / s_{i}$.

We get the normalised indexes weights of the integrated risk in Table 6 . Table 6 presents the normalised indexes weights of different layers' indexes.

Table 6 Normalised indexes weights of integrated risk

\begin{tabular}{|c|c|c|c|}
\hline First-layer index & Weight & Second-layer index & Weight \\
\hline \multirow{4}{*}{ Credit risk $\left(X_{1}\right)$} & \multirow{4}{*}{0.4215} & Non-performing loan ratio $\left(X_{11}\right)$ & 0.2538 \\
\hline & & Estimated loan loss ratio $\left(X_{12}\right)$ & 0.0621 \\
\hline & & Ratio of the largest single loan $\left(X_{15}\right)$ & 0.3267 \\
\hline & & Ratio of 10 largest loans $\left(X_{16}\right)$ & 0.3574 \\
\hline \multirow{2}{*}{ Market risk $\left(X_{2}\right)$} & \multirow{2}{*}{0.2065} & Risk-sensitive ratio of interest rate $\left(X_{21}\right)$ & 0.5676 \\
\hline & & Accumulated foreign exchange exposure positions ratio $\left(X_{22}\right)$ & 0.4324 \\
\hline \multirow[t]{2}{*}{ Operational risk $\left(X_{3}\right)$} & 0.0956 & The volatility of non-interest expenditure $\left(X_{31}\right)$ & 1.0000 \\
\hline & & Liquidity ratio $\left(X_{42}\right)$ & 0.2940 \\
\hline \multirow[t]{2}{*}{ Liquidity risk $\left(X_{4}\right)$} & 0.2764 & Loan-deposit ratio $\left(X_{43}\right)$ & 0.3367 \\
\hline & & Inter-bank borrowings ratio $\left(X_{44}\right)$ & 0.3693 \\
\hline
\end{tabular}

In this table, we can see that the weight of credit risk $\left(X_{1}\right)$ is the biggest and the weight of operational risk is the smallest. The ratios of ten largest loans $\left(X_{16}\right)$ are the most important variables in the credit risk. The weight of $X_{21}$ is higher than that of $X_{22}$. The weight of inter-bank borrowings ratio $\left(X_{44}\right)$ is higher than that of the others.

\subsection{Elements sets}

Elements sets include index set, weight set, evaluation set and subjection degree matrix. These sets are given by vectors (see Chi et al., 2009). We use these sets to calculate the early warning factors of different risks and integrated risk.

- Index set: The first-layer index set:

$$
X=\left(X_{1}, X_{2}, X_{3}, X_{4}\right)
$$

- The second-layer index set:

$$
X_{1}=\left(X_{11}, X_{12}, X_{15}, X_{16}\right)
$$




$$
\begin{aligned}
& X_{2}=\left(X_{21}, X_{22}\right) \\
& X_{3}=\left(X_{31}\right) \\
& X_{4}=\left(X_{42}, X_{43}, X_{44}\right)
\end{aligned}
$$

- Weight set: According to Table 6, we can get equations (11)-(15). The first-layer index weight set:

$$
w=\left(w_{1}, w_{2}, w_{3}, w_{4}\right)=(0.42,0.21,0.10,0.28)
$$

- The second-layer index weight set:

$$
\begin{aligned}
& w_{1}=\left(w_{11}, w_{12}, w_{15}, w_{16}\right)=(0.25,0.06,0.33,0.36) \\
& w_{2}=\left(w_{21}, w_{22}\right)=(0.57,0.43) \\
& w_{3}=\left(w_{31}\right)=(1) \\
& w_{4}=\left(w_{42}, w_{43}, w_{44}\right)=(0.29,0.34,0.37)
\end{aligned}
$$

- Evaluation set:

$$
V_{m}=\left(V_{1}, V_{2}, V_{3}, V_{4}\right)
$$

$V_{m}$ represents the different grade of risk. ' 1 ' means non-risk, '2' light risk, ' 3 ' middle risk and ' 4 ' serious risk.

- Subjection matrix: The first-layer index subjection:

Matrix $R=\left(R_{1}, R_{2}, R_{3}, R_{4}\right)^{\mathrm{T}}$

- The second-layer index subjection degree matrix:

$$
\begin{aligned}
& R_{1}=\left(r_{11}, r_{12}, r_{15}, r_{16}\right)^{\mathrm{T}} \\
& R_{2}=\left(r_{21}, r_{22}\right)^{\mathrm{T}} \\
& R_{3}=\left(r_{31}\right)^{\mathrm{T}} \\
& R_{4}=\left(r_{42}, r_{43}, r_{44}\right)^{\mathrm{T}}
\end{aligned}
$$

The subjection degree of forward index is calculated by

$$
r_{i j}\left(V_{1}\right)= \begin{cases}0, & v_{0} \leq x \leq v_{2} \\ \frac{x-v_{2}}{v_{3}-v_{2}}, & v_{2} \leq x \leq v_{3} \\ 1, & v_{3} \leq x \leq v_{4}\end{cases}
$$




$$
\begin{aligned}
& r_{i j}\left(V_{2}\right)= \begin{cases}0, & v_{0} \leq x \leq v_{2} \\
\frac{v_{3}-x}{v_{3}-v_{2}}, & v_{2} \leq x \leq v_{3} \\
0, & v_{3} \leq x \leq v_{4}\end{cases} \\
& r_{i j}\left(V_{3}\right)= \begin{cases}0, & v_{0} \leq x \leq v_{1} \\
\frac{x-v_{1}}{v_{2}-v_{1},} & v_{1} \leq x \leq v_{2} \\
0, & v_{0} \leq x \leq v_{1}\end{cases} \\
& r_{i j}\left(V_{4}\right)= \begin{cases}1, & v_{0} \leq x \leq v_{1} \\
\frac{v_{2}-x}{v_{2}-v_{1}}, & v_{1} \leq x \leq v_{2} \\
0, & v_{2} \leq x \leq v_{4}\end{cases}
\end{aligned}
$$

The subjection degree of backward index is calculated by

$$
\begin{aligned}
& r_{i j}\left(V_{1}\right)= \begin{cases}1, & v_{0} \leq x \leq v_{\mathrm{I}} \\
\frac{v_{2}-x}{v_{2}-v_{1}}, & v_{\mathrm{l}} \leq x \leq v_{2} \\
0, & v_{2} \leq x \leq v_{4}\end{cases} \\
& r_{i j}\left(V_{2}\right)= \begin{cases}0, & v_{0} \leq x \leq v_{1} \\
\frac{x-v_{1}}{v_{2}-v_{1}}, & v_{1} \leq x \leq v_{2} \\
0, & v_{2} \leq x \leq v_{4}\end{cases} \\
& r_{i j}\left(V_{3}\right)= \begin{cases}0, & v_{0} \leq x \leq v_{2} \\
\frac{v_{3}-x}{v_{3}-v_{2}}, & v_{2} \leq x \leq v_{3} \\
0, & v_{3} \leq x \leq v_{4}\end{cases} \\
& r_{i j}\left(V_{4}\right)= \begin{cases}0, & v_{0} \leq x \leq v_{2} \\
\frac{x-v_{2}}{v_{3}-v_{2}}, & v_{2} \leq x \leq v_{3} \\
1, & v_{3} \leq x \leq v_{4}\end{cases}
\end{aligned}
$$

In the above, $x$ means $X_{\mathrm{ij}}$ and $v_{i}(i=0,1,2,3,4)$ means the boundary value of each risk grade according to the limit in Table 1 . The definite $v_{i}(i=0,1,2,3,4)$ is given by 
Table 7. $V_{i}(i=0,1,2,3,4)$ means the degree of different risks. According to the limit in Table 1, 'risk evaluation system of commercial banks (interim)' and 'commercial bank regulatory risk core index (interim)' (China Banking Regulatory Commission, 2004, 2005), the boundary values of each risk grade are presented in Table 7.

Table 7 The boundary value of each risk grades

\begin{tabular}{lcccc}
\hline \multicolumn{1}{c}{ Index } & $\begin{array}{c}\text { Non-risk } \\
\left(V_{l}\right)\end{array}$ & $\begin{array}{c}\text { Light risk } \\
\left(V_{2}\right)\end{array}$ & $\begin{array}{c}\text { Middle risk } \\
\left(V_{3}\right)\end{array}$ & $\begin{array}{c}\text { Serious risk } \\
\left(V_{4}\right)\end{array}$ \\
\hline Non-performing loan ratio $\left(X_{11}\right)$ & $\leq 5$ & $(5,8)$ & $(8,10)$ & $\geq 10$ \\
Estimated loan loss ratio $\left(X_{12}\right)$ & $\leq 3$ & $(3,6)$ & $(6,15)$ & $\geq 15$ \\
Ratio of the largest single & $\leq 9$ & $(9,12)$ & $(12,15)$ & $\geq 15$ \\
loan $\left(X_{15}\right)$ & $\leq 45$ & $(45,55)$ & $(55,65)$ & $\geq 65$ \\
Ratio of 10 largest loans $\left(X_{16}\right)$ & $(1,1.05)$ & $(1.05,1.1)$ & $(1.1,1.15)$ & $(1.15,1.2)$ \\
Risk-sensitive ratio of interest & & & & \\
rate $\left(X_{21}\right)$ & $\leq 18$ & $(18,25)$ & $(25,40)$ & $\geq 40$ \\
Accumulated foreign exchange & & & & \\
exposure positions ratio $\left(X_{22}\right)$ & $\leq 40$ & $(40,50)$ & $(50,60)$ & $\geq 60$ \\
The volatility of non-interest & $\geq 30$ & $(20,30)$ & $(15,20)$ & $\leq 15$ \\
expenditure $\left(X_{31}\right)$ & $\leq 70$ & $(70,80)$ & $(80,85)$ & $\geq 85$ \\
Liquidity ratio $\left(X_{42}\right)$ & $\leq 4$ & $(4,6)$ & $(6,8)$ & $\geq 8$ \\
Loan-deposit ratio $\left(X_{43}\right)$ & & & & \\
Inter-bank borrowings ratio $\left(X_{44}\right)$ & & & &
\end{tabular}

In the elements set, $r$ means the subjection degree between index and risk. The nearer $r_{i j}$ closes to 1 , the higher degree $x$ belongs to $V$. The nearer $r_{i j}$ closes to 0 , the lower degree $x$ belongs to $V$.

Let

$$
\begin{aligned}
& B_{1}=w_{1} * R_{1} \\
& B_{2}=w_{2} * R_{2} \\
& B_{3}=w_{3} * R_{3} \\
& B_{4}=w_{4} * R_{4}
\end{aligned}
$$

and $\lambda=(1,2,3,4)$. Then, we can get the early warning factors of different risks and integrated risks:

Early warning factor of credit risk:

$$
\beta_{1}=\lambda^{*} B_{1}^{\mathrm{T}}
$$

Early warning factor of market risk:

$$
\beta_{2}=\lambda^{*} B_{2}^{\mathrm{T}}
$$

Early warning factor of operational risk:

$$
\beta_{3}=\lambda^{*} B_{3}^{\mathrm{T}}
$$


Early warning factor of liquidity risk:

$$
\beta_{4}=\lambda * B_{4}^{\mathrm{T}}
$$

Early warning factor of integrated risk:

$$
\beta=w^{*}\left(\beta_{1}, \beta_{2}, \beta_{3}, \beta_{4}\right)^{T}
$$

\section{Empirical analysis}

Here, empirical analysis means that we will calculate the integrated risk of four Chinese commercial banks with fuzzy comprehensive appraisal method. According to the above calculated method, we can get the warning factors of different risks in ICBC firstly.

Based on the 2008 data of Chinese commercial banks in Table Al and the calculated method of the indexes subjection degree expressed by equations (22)-(29), we can get the subjection degree of every risk.

Credit risk subjection degree:

$$
R_{1}=\left(r_{11}, r_{12}, r_{15}, r_{16}\right)^{\mathrm{T}}=\left(\begin{array}{llll}
1 & 0 & 0 & 0 \\
1 & 0 & 0 & 0 \\
1 & 0 & 0 & 0 \\
1 & 0 & 0 & 0
\end{array}\right)
$$

Market risk subjection degree:

$$
R_{2}=\left(r_{21}, r_{22}\right)^{\mathrm{T}}=\left(\begin{array}{llll}
0.54 & 0.46 & 0 & 0 \\
1.00 & 0.00 & 0 & 0
\end{array}\right)
$$

Operational risk subjection degree:

$$
R_{3}=\left(r_{31}\right)^{\mathrm{T}}=(0.06,0.94,0,0)
$$

Liquidity risk subjection degree:

$$
R_{4}=\left(r_{42}, r_{43}, r_{44}\right)^{\mathrm{T}}=\left(\begin{array}{llll}
1 & 0 & 0 & 0 \\
1 & 0 & 0 & 0 \\
1 & 0 & 0 & 0
\end{array}\right)
$$

Then we put the weight and subjection degree of each risk into equations (30)-(33):

$$
\begin{aligned}
& B_{1}=w_{1}^{*} R_{1}=(0.25,0.06,0.33,0.36) *\left(\begin{array}{cccc}
1 & 0 & 0 & 0 \\
1 & 0 & 0 & 0 \\
1 & 0 & 0 & 0 \\
1 & 0 & 0 & 0
\end{array}\right)=(1,0,0,0) \\
& B_{2}=w_{2}^{*} R_{2}=(0.57,0.43) *\left(\begin{array}{llll}
0.54 & 0.46 & 0 & 0 \\
1.00 & 0.00 & 0 & 0
\end{array}\right)=(0.74,0.26,0,0)
\end{aligned}
$$




$$
\begin{aligned}
& B_{3}=w_{3}^{*} R_{3}=1 *(0.06,0.94,0,0)=(0.06,0.94,0,0) \\
& B_{4}=w_{4}^{*} R_{4}=(0.29,0.34,0.37) *\left(\begin{array}{llll}
1 & 0 & 0 & 0 \\
1 & 0 & 0 & 0 \\
1 & 0 & 0 & 0
\end{array}\right)=(1,0,0,0)
\end{aligned}
$$

According to equations (34)-(38), we calculate the early warning factor of each risk.

Early warning factor of credit risk:

$$
\beta_{1}=\lambda^{*} B_{1}^{\mathrm{T}}=(1,2,3,4)^{*}(1,0,0,0)^{\mathrm{T}}=1
$$

Early warning factor of market risk:

$$
\beta_{2}=\lambda^{*} B_{2}^{\mathrm{T}}=(1,2,3,4)^{*}(0.74,0.26,0,0)^{\mathrm{T}}=1.2622
$$

Early warning factor of operational risk:

$$
\beta_{3}=\lambda^{*} B_{3}^{\mathrm{T}}=(1,2,3,4)^{*}(0.06,0.94,0,0)^{\mathrm{T}}=1.944
$$

Early waming factor of liquidity risk:

$$
\beta_{4}=\lambda^{*} B_{4}^{\mathrm{T}}=(1,2,3,4)^{*}(1,0,0,0)^{\mathrm{T}}=1
$$

The early warning factor of integrated risk:

$$
\beta=w^{*}\left(\beta_{1}, \beta_{2}, \beta_{3}, \beta_{4}\right)^{\mathrm{T}}=(0.42,0.21,0.10,0.28)^{*}(1,1.26,1.94,1)^{\mathrm{T}}=1.1443
$$

In the same way, we can get the early warning factor of risk in the other three commercial banks. The values are given in Table 8 . In the table, $\beta_{i}(i=1,2,3,4)$ means the warning factors of different risks and $\beta^{\prime}$ means the mean value of these four risk warning factors. $\beta$ is the warning factor of integrated risk. The bigger the value of $\beta_{i}, \beta^{\prime}$ or $\beta$ is, the higher the risk is. Table 8 presents the calculated results among these Chinese commercial banks.

Table 8 Early warning factor of risk in banks

\begin{tabular}{lcccc}
\hline & $I C B C$ & $C C B$ & SPDB & CMB \\
\hline Credit risk $\left(\beta_{1}\right)$ & 1.0000 & 1.0000 & 1.0000 & 1.0000 \\
Market risk $\left(\beta_{2}\right)$ & 1.2622 & 1.0000 & 1.4756 & 1.0000 \\
Operational risk $\left(\beta_{3}\right)$ & 1.9440 & 1.0000 & 3.2550 & 3.2980 \\
Liquidity risk $\left(\beta_{4}\right)$ & 1.0000 & 1.2793 & 1.1135 & 1.0960 \\
Mean value $(\beta)$ & 1.3016 & 1.0698 & 1.7110 & 1.5985 \\
Integrated risk $(\beta)$ & 1.1443 & 1.0577 & 1.3452 & 1.2462 \\
\hline
\end{tabular}

From Table 8, we can see the risk degrees of CCB and ICBC are lower than those of SPDB and CMB, especially $\beta_{3}$. It indicates that SPDB and CMB faced bigger operational risks in 2008 . In Table $8, \beta^{\prime}$ means the mean value of these four risk warning factors ignoring the correlations between risks and $\beta$ is the warning factors of the integrated risk 
considering the correlations between risks. From Table 8 , we can also see that $\beta^{\prime}$ is higher than $\beta$ in all Chinese commercial banks. This means, if we ignore the correlations between risks, the whole risk will be overestimated. Then we can draw a conclusion that the result of many kinds of risks studied as a whole is better than simply the sum of all the risks. Without considering the correlation between these risks, the simple linear weighted sum of these risks will expand the integrated risk.

\section{Conclusion}

Based on the structure of fuzzy comprehensive appraisal method, this paper calculated the integrated risk warning factors of four Chinese commercial banks. The paper also tried to measure the integrated risk including operational risk, even though the exact data for operational risk are not obtainable due to the privacy of banks.

In Table 8, the risk degrees of CCB and ICBC are lower than those of SPDB and CMB. In addition, from this form, we can see that the mean value of the four risks ignoring the correlations will be higher than the integrated risk of the four risks. This means the whole risk will be overestimated. This is not beneficial to the allocative efficiency of financial resources.

Because of the correlation between different kinds of risks, we should study these kinds of risks as a whole. Without considering the influence of correlation, future research results can easily depart from reality. For this reason, we should consider the correlation among different risks when we study the risks faced by commercial banks.

\section{Acknowledgements}

H.L. acknowledges financial support from Liaoning University Young Science Foundation Programmes (Grant No. 2011LDQN10) and the National Natural Science Foundation of China (Grant No. 11101198).

\section{References}

Basel Committee on Banking Supervision (2006) Sound Credit Risk Assessment and Valuation for Loans, Bank for Intemational Settlements Press \& Communications, Basel, Switzerland.

Chen, S. (2003) 'The research for statistics method of risk ratings', Statistics and Decision, pp. $8-10$.

Chi, G., Feng, X. and Zhao, Z. (2009) 'Waming model of operating risk for commercial banks and its empirical study', Journal of Systems Engineering, Vol. 24, pp.410-413.

China Banking Regulatory Commission (2004) Risk evaluation system of commercial banks (interim). Available online at: http://www.cbrc.gov.cn/govView_17594AA780594C5 EBF8250E2EA25BEE3.html.

China Banking Regulatory Commission (2005) Commercial bank regulatory risk core index (interim). Available online at: http://www.cbrc.gov.cn/chinese/home/docDOC_ReadView/ 2196.html. 
Frankel, J.A. and Rose, A.K. (1996) 'Currency crashes in emerging markets: an empirical treatment', Jommal of International Economics, Vol. 41, pp.351-366.

$\mathrm{He}, \mathrm{X}$. and Zhang, Y. (2001) 'The establishment of risk pre-warning system of commercial banks and an empirical analysis', Finance Form, Vol. 6, pp.32-36.

Jolliffe, I.T. (2002) Principal Component Analysis, 2nd ed., Springer-Verlag, New York, pp.29-77.

Rosenberg, J.V. and Schuermann, T. (2006) 'A general approach to integrated risk management with skewed, fat-tailed risks', Joumal of Financial Economics, Vol. 79, pp.569-614.

Verma, J.P. (2013) Data Analysis in Management with SPSS Software, Springer India, New Delhi, pp. $317-353$.

Zhang, X. and Huang, J. (2003) 'The research for evaluation index system and comprehensive appraisal method of financial risk', Statistics \& Information Fonum, pp.34-37. 


\section{Appendix A}

Table A1 The original data of the four Chinese commercial banks in 2008. The limits are according to the requirements of 'risk evaluation system of commercial banks (interim)' and 'commercial bank regulatory risk core index (interim)' (China Banking Regulatory Commission, 2004, 2005)

\begin{tabular}{lccccc}
\hline & $I C B C$ & $C C B$ & SPDB & CMB & Limit \\
\hline Non-performing loan ratio $\left(X_{11}\right)$ & 2.29 & 2.21 & 1.21 & 1.11 & $<5 \%$ \\
Estimated loan loss ratio $\left(X_{12}\right)$ & 2.0866 & 2.0226 & 1.5151 & 1.7078 & $<3 \%$ \\
Mortgage loan ratio $\left(X_{13}\right)$ & 51.70 & 54.06 & 45.46 & 37.81 & $>25 \%$ \\
NPL provisioning coverage ratio $\left(X_{14}\right)$ & 130.15 & 131.58 & 192.49 & 223.29 & $>75 \%$ \\
Ratio of the largest single loan $\left(X_{15}\right)$ & 2.90 & 3.68 & 2.96 & 5.31 & $<10 \%$ \\
Ratio of 10 largest loans $\left(X_{16}\right)$ & 20.40 & 20.72 & 24.3 & 32.14 & $<50 \%$ \\
Risk-sensitive ratio of interest rate $\left(X_{21}\right)$ & 1.0731 & 1.0746 & 1.0329 & 1.0919 & 16 best \\
Accumulated foreign exchange & 8.77 & 3.09 & 14.34 & 11.53 & $<20 \%$ \\
exposure positions ratio $\left(X_{22}\right)$ & & & & & \\
The volatility of non-interest & 49.44 & 32.01 & 52.98 & 52.55 & $<50 \%$ \\
expenditure $\left(X_{31}\right)$ & 14.5 & 14.5 & 13.5 & 13.5 & $>13.5 \%$ \\
Reserve requirement ratio $\left(X_{41}\right)$ & 33.3 & 52.74 & 55.24 & 43.14 & $>25 \%$ \\
Liquidity ratio $\left(X_{42}\right)$ & 56.4 & 57.77 & 72.85 & 74.17 & $<75 \%$ \\
Loan-deposit ratio $\left(X_{43}\right)$ & 0.65 & 0.08 & 1.12 & 3.52 & $<4 \%$ \\
Inter-bank borrowings ratio $\left(X_{44}\right)$ & & & &
\end{tabular}

